\title{
ステロイド療法後に発現した䫟炎の一例について
}

\author{
熊本大学医学部附属病院歯科口腔外科（指導：田縁 昭講師） \\ 田縁昭・緒方義昌 \\ 坂 梨 常太郎・柿 原. 康 男
}

(昭和44年12月17日受理)

（本論の要旨は第14回日本口腔外科学会総会に拈いて報告した）

\section{A CASE REPORT OF JAW INFLAMMATION AFTER STEROID THERAPY}

\section{By}

\begin{abstract}
Akira TAEN, Yoshimasa OGATA, Jootaroo SAKANASHI and Yasuo KAKIHARA
\end{abstract}
Dental Clinic of Medical School (Director: Lec. Akira TAEN)

Kumamoto University, Kumamoto, Japan

Generally it is well Known that the steroid agents have strong antiphilogistic actions. Therefore, when the steroid agent is clinically used, antibiotic agents must be used, at the same time, for secondary infection.

The authors experienced a case of serious mandible inflammation from secondary infection, in which case, the patient had been for 5 years treated for nephlitis with the steroid agents without antibiotics.

The patient was a female, 24 years old, and complained of swelling, bleeding, a spontaneous pain in 8 area, and paralysis of the left mandible and the lower lip.

We treated the patient with antibiotics and non-steroid antiphilogistic agents, discontinuing the administration of the steroid agents.

A successful result in extracting causal teeth was obtained.

緒言

副腎皮質ステロイド剤は，1948年 Hench 等がロイマ チス性疾患に使用して劇的な効果を得て以来，㕕く各科 領域で種々の疾患の治療に怙いて用いられている，その 投与量は，補償療法の場合を除いて一般にかなり大量 が，比較的長期間に用いられるために，その強力な抗炎 症作用，電解質の代謝不全などによる，副作用の発現は 避け難く，ときには重篤な合併症を招くことがあるとさ れている1〜3).

また一旦ステロイド療法を開始すると，これが長期に およぶ場合には，休薬に達することが比較的困難で，中 止にあたって症状の再燃や不快な合併症に悩まされるこ とも稀ではなく，その使用については充分な考慮のもと に行なわなければならないとされている。
最近，われわれは腎疾患の治療に際して副腎皮質ステ ロイド剤の大量，汃長期にわたる投与中，その易感染 性に対する対策がなされなかったために発現したと思わ れる重篤なる顎炎の一例について経験したので，その概 要について報告する。

\section{店 例}

患者：向○君○24才 女性

初䛦：昭和41年 1 月22日

主訴：左側下靧体部の腫脹と跭痛.

家族歷・生活歷 : 特記事項なし.

既往病歴：10才の時に腎炎の診断をうけ，某医で処置 をうけ軽快した。昭和39年 8 月に至り腎炎の再燃を来た し, 昭和41年, 42年, 43年亡入院之通院をくりかえし, その後四肢の浮腫があらわれたため，ステロイド療法が 
開始されたが症状は好転せず，昭和43年 7 月に至り再度 某医に入院後,さらに副腎皮質ステロイド剤の大量連続 投与が行なわれたが，乙の間抗生剂の投与はうけなかっ た。

現病歴：昭和 43 年10月下旬, 上記疾患のステロイド療 法中, 左側下顎智㐘周囲の菡肉の異和感を自賞し,さら に同部の周柬㐘肉の腫脹と疼痛があったが，特に処置は 受けず放置された。11月上旬，同部周用歯肉の腫脹之終 痛が著明よなり，某画科医を訪れ，切開排膿を受けたが 症状は一進一退をなし，43年11月下旬より下顎左側小曰 歯部より智歯後縁部にかけ歯肉の剥離を生じ, 出血, 腫 脹, 疼痛等の症状が軽快しないので, 抗生剂の投与をう けたところ症状は緩解した。

昭和 44 年1月20日に至り，再び同部歯肉，ならびに左 側下顎体部, 上行枝部の腫脹, 発赤, 疼㿑があり, 左側 下顎智菌周囲部よりの自然排膿を来たした。 その直後よ り小曰歯部から智歯後縁までの㐘肉の剥離之同部よりの 出血之，左側下顎第 1小目蒾より智歯部までの歯牙の 動摇, 著明な接触痛を来たし, 熱発之開口障害, 䓵下障 害, 外煩部から耳下腺咬筋部の浮腫性腫脹等が著明とな り，ワンサン氏症候の出現をみ，再び某医において消炎 処置を行なったが症状の改善が全くみられないので当科 に紹介されたものである。な抢ての間ステロイド剂は引 続き投与されていた。

現症・全身所見：顔貌は非対称性, 満月状で体格は肥 満している，鼻下部には男性化した影の発現があり，顔 色は不良, 皮䖉の色調は黄色, 加乾燥し全身的な浮腫 を認める。

左側の口唇, 䫟体部, 下顎角部, 上頸部, 上肢の知賞 麻痺があり歩行は不能である。

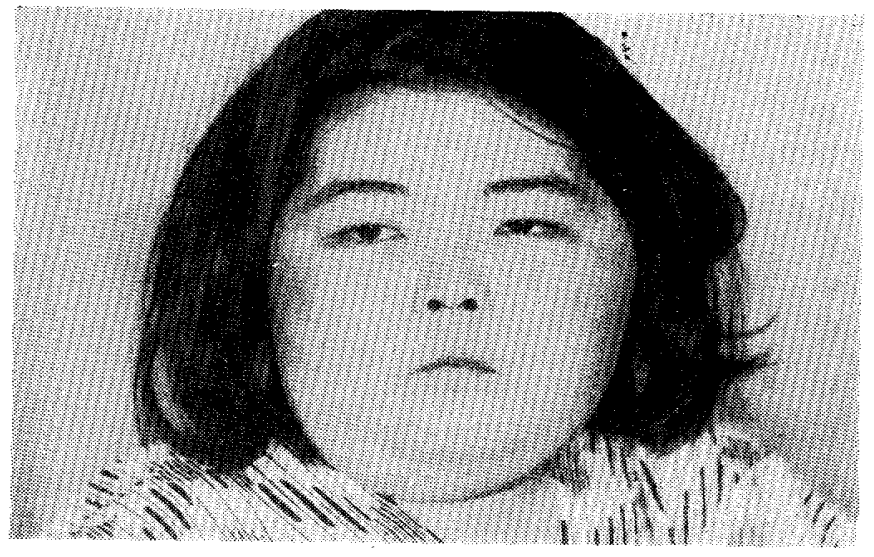

写真 1 来院時顔貌

局所所見：左側下顎体部より顎下，上頸部にかけ，発 赤を併った浮腫様腫脹があり左下唇はやや下垂して知覚
異常を認める。開口は一横指，口腔内は口気覀臭が著明 で柬牙には多量の歯垢の附着があり不潔である。歯牙。 久損はなく，左側下顎第上小曰霜部より智歯部にわたり 歯牙の動摇之接触痛があり，同部の煩側歯頸部より，菌 肉頓移行部まで粘膜は剥離し，その部は新鮮な血餅で年 満されている，左側下顎体部の剥離した歯肉はやや荅追 で弁状，可動性である，その歯肉弁は血餅を除去すると 暗黒色を呈し，少量の膿汁を認める。骨膜が剥離した省 面は粗造でやや淡黄白色で，剥離した蒾肉部より骨面に ゾンデを插入すると，上行枝下顎切痕，下顎角部附近す で骨膜の剥離が認められる，触診により，智蒾部よりの 出血上疼痛を訴えるが波動は触れない，上線所見におい ては，原部に軽度の歯槽骨の吸収がみられる以外，著 変はみられない，左顎下リンパ節は拇指頭大のもの1但 をふれ，圧消が著明である。

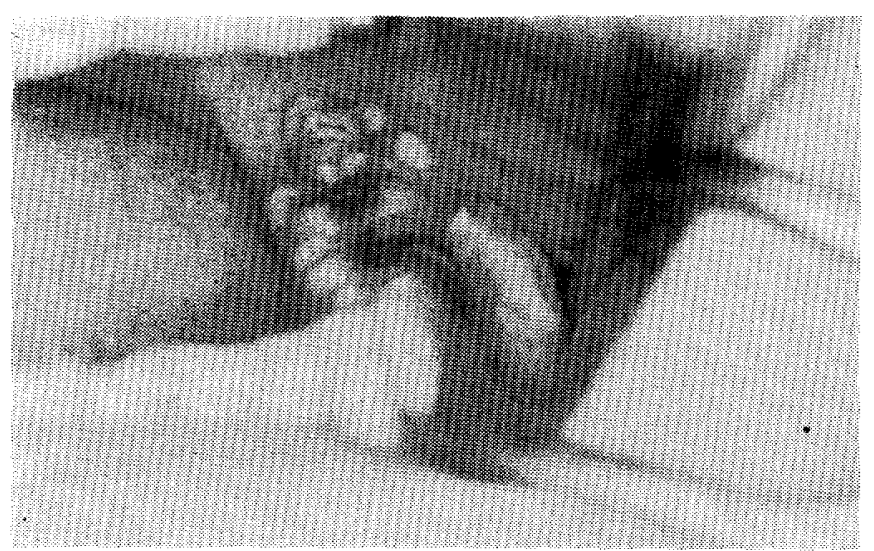

写真 2 来院時口腔内所見

臨床診断：左側急性下顎骨々髄炎.

処置および経過：昭和 4 年 1 月22日直 5に入院せ め, Sigmamycin の点滴静注を1日2回行ない，止向 剂ならびに消炎剂の投与も併せて行なった。さらにリン デロン1.5mg 在投与した。歯肉が剥離，露出した骨面 は，保護的に洗深し，含嗽をくりかえしさせたところ， 2 日目に剥離した骨面上の血餅は消失し，骨が露出した 5 日目に至り開口は 2 横指, 嚥下痛は軽度となり，入陵 後 7 日目で顎炎の症状はさらに好転をみ，開口障害，些 下障害の改善をみたので，本学第 3 内科之対診の結果， 第三内科入転科させた。

第 3 内科において，Parameson - Lincosin - Keflodir ・Sigmamycin を約 2 力月間投与を受けたところ，苗肉 剥離部上りの出血は消失した。3 月13日に至り，ステロ イド剤の減量が行なうれた。との時期には，露出した骨 面の表面は一層の薄い肉芽に上って被われ，剥離した骨 面はゾンデが約 $1 \mathrm{~cm}$ 挿入される程度となり，口腔粘胋 
は比較的清潔になった。

昭和 44 年 4 月に至り，満月様顔貌毛消退し，抗生剂之 ステロイド剤をさらに漸次減量するとともに消炎剤等の 投与を持続した。7 月に至り抗生剂は常用量まで減量 し，8月6日には副腎皮質ステロイド剂の投与を中止し た。腎炎の症状も軽快し，口腔内の㐘肉の䟝離した骨面 もほとんど粘膜で被われ、ゾンデの挿入も不能となった。 智歯周国のレ線所見屯歯槽骨の軽度の吸収以外の異常所 見は認められない。

8月28日に至り通法により，本顎炎の原因歯と考えら れる，左側下顎智料を抜去した，抜去歯牙は歯頸緣下ま で, 多量の歯石の沈着珰めた。抜去後，出血，顎炎の 再燃等の不快事項もなく創面は治癒した。

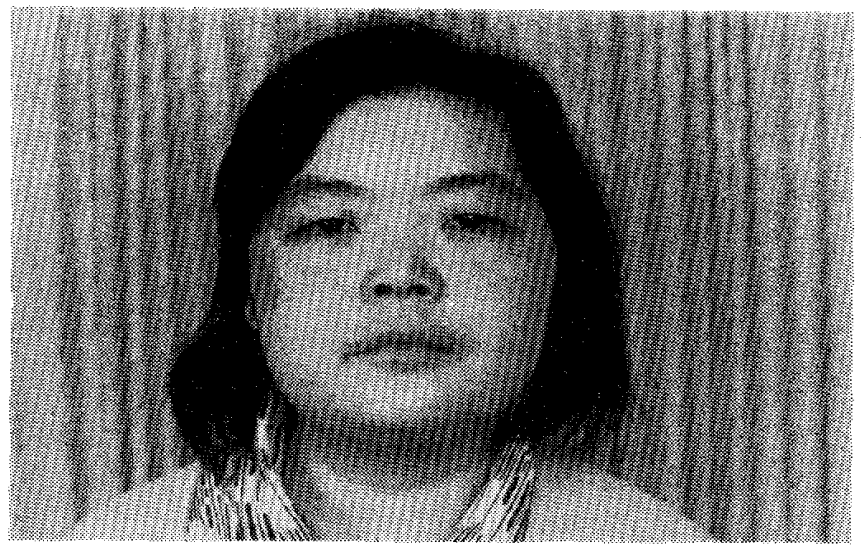

写真 3 退院時顔貌

\section{総 括ならびに考按}

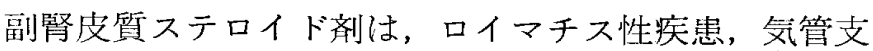
喘息，ネフローゼなよ゙に使用されており，劇的効果を得 る場合も少なくない，本偊の副作用としては，すでに多 数の報告 1-9)があるが，三宅は，1）感染症，2）消化 管合併症，3）精神障害，4）急性副腎皮質不全，5）

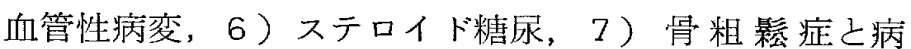
的骨折，8）ステロイド関節症 9) ステロイド筋症， 10）眼科的合併症，11）その他の合併症，12）渏形の発 生などがあるとしている。さらにステロイド剂の療法の 中止の際の合併症としては，1）原疾患の反跳，悪化，

2) Steroid Withdrawal Syndrome，3）急性副警皮 質不全なよ゙が上げられている。副作用の症状としては， 重篤な場合は，吐血，下血，胃潰瘍，感染症があり，軽 度のものでは, 満月様顔貌，上腹部不快感，不眠，昰 心, 嘔吐, 頭痛, 食思不振, 坐愴, 浮腫, 男性化, 高血 圧，皮膚線条，糖㽷，高コレステロール血症， $\mathrm{Na} / \mathrm{K}$ 比 増加, 潜血反応, 精神症状があげられている。長期間に わたるステロイド療法よりの離脱に際しては大量を長期
間用いた場合に，前述のごとき種々の副作用は避け難い といわれている。したがって，副腎皮質ステロイド剂に より原疾患が好転した場合には，すみやかな離脱をはか らねばならないと共に投与期間中は，各種感染症に対し て毛充分に意を用いなければならないままた離脱に際し ては原疾患の再然や，前述のごとく不快な合併症を伴な うことが少くないとされている。

副腎皮質ステロイド剂の離脱に関しては種々の万法が 上げられて扣り，1) 漸減法及び少量維持療法，2）間 歇投与法，3）ACT Hの併用，4）蛋白同化ステロイ ド剂の併用などがある4).

歯科口腔外科領域に発現する，他咨患の治療における 薬剂の副作用は，すでに多数あげられているが，それら はいずれも薬用の中止により，比較的すみやかに症状の 消失がみられる。しかしながら副腎皮質ステロイド剂の 場合には，本剂の中止，休薬については前述のごとく間 題点がある．副作用の出現あ数多く報告されている．真 下10)によれば上述のごとき不快事項の発現，ことに感染 症の併発力゙予想される場合には抗生剤の併用を行なう事 老強調している。特に口腔内は，病源性微生物加常在し ており感染に関して充分に意を用いなければならない。 本症例に执いては，腎疾患の治療に際して長期にわた り，副腎皮質ステロイド剤の連用を行なったにもかかわ らず，感染症に対する考慮がほとんど行なわれず，その ため一度発現した口腔内の軽度の炎症が一旦消炎後, 再 び再燃し広範囲な部にわたり炎症が進行し歯肉, 婴膜の 剥離を来たし，さらに重篤な顎炎の症状を示したもので ある。本症の場合，乙の時期にすでに満月様顔貌，男性 化現象などの副腎皮質ステロイド剂の副作用ともみるべ き症状が発現して抢り，すみやかに本剂からの，離脱が 考虑されなければならなかった症例であると考えられ る。このような見地から，本症に対しては，感染症に対 する多量の抗生剤の投与と共に漸減的に副腎皮質ステロ イド剤の投与を行ないかつ腎疾患の処置を併せて行ない つつ，6力月後に副腎皮質ステロイド剂の離脱と原疾患 の軽快，ならびに感染症の治癒をみたものであり，さら に充分なる注意のもとに原因歯牙の抜去を行ない，何等 の不快事項の発現をみる事なく治癒し，入院後，8力月 で退院，現在まで口腔内感染症の発現をみない．

副撉皮ステロイド剂は，顎，口腔領域に抢いても種々 の疾患に対して使用されるが，同時に二次的に合併する 感染症に対してあ充分考慮し，抗生用，化学療法剂の併 用を行ないつつ，加原笑患の治療に充分の效果を得た ならば，すみやか副㹂皮質ステロイド剂からの離脱を 
行ない, 離脱に際しては, Withdrawal Syndromeなど にあ充分考慮すべきである。

\section{結論}

1）われわれは腎疾患の治療に際して長期間にわた る，副腎皮質ホルモン剂の投与中，二次的に合併した之 思われる顎炎の1 例について経験した。

2) 本症例に対し，充分なる抗生剂，消炎剂の投与を 行ない，顎炎の消退を行ない得た。

3）副腎皮質ステロイド剤からの離脱が完了した時期 に, 二次的感染症の原因と考えられる，左側下㖠智歯の 抜去を行ない，良好な結果が得られた。

\section{参考文 献}

1. 熊谷 明; 日本に於ける Glucocorticoid の大きな 副作用就ての調查成績 : Endocrinologia

Japonica, 12 ( 3 ), 36-46, (1965).

2. 横田素一郎; 副憼皮質 Hormone 療法の副作用 : 日 赤医学, 18 (4), 10-19, (1966).

3. 高橋幸雄, 武田 明, 西野 動; Steroidhormone
療法における副作用の検討：新潟医学会雑誌，79 ( 3 ), 276-277, (1965).

4. 三宅 儀; 副腎皮質 Steroid の副作用之離脱法の検 討：治療，48（2），422-430，(1966).

5. 小堀辰治; 皮度科領域に於ける副腎皮質 Hormone 全身投与に因る副作用：日本皮膚科学会雑誌，8

( 2) , 123-197, (1966).

6. 熊谷 明; 副腎皮質 Hormone 療法に於汀る消化性 潰場出血に因る重篤な副作用と其対策に関する基礎 的研究：アレルギー，14（6），403-404，(1965).

7 . 徳山一郎; 副腎皮質 Steroid の副作用内科的立場 より：皮庿上泌尿，28（3），428，(1966).

8. 勝正 孝; 副腎 Steroid 誘発感染症之 Aspergillus 症：日本伝染病学会雑誌，41（6），219-232, (1967)

9. 竹本吉夫; 副腎皮質 Steroid 療法の副作用防止策 ：日本医事新報，2233（2），103，(1967）.

10. 真下啓明; 感染症と副腎ホルモン：内科, 2(3), $472-479$, (1958). 